\title{
Biflavonoids from an Ethno-Medicinal Plant Ochna holtzii Gilg
}

Awadh $\mathrm{MM}^{1 *}$, Tarus $\mathrm{PK}^{2}$, Onani $\mathrm{MO}^{3}$, Machocho $\mathrm{AK}^{1}$ and Hassanali $\mathrm{A}^{1}$

${ }^{1}$ Department of Chemistry, Kenyatta University, P.O. Box 43844-00100, Nairobi, Kenya

${ }^{2}$ Department of Chemistry and Biochemistry, University of Eldoret, P.O. 1125 - 30100, Eldoret, Kenya

${ }^{3}$ Department of Chemistry, University of Western Cape, Private Bag X17, Bellville, 7535, South Africa

\begin{abstract}
Ochna holtzii Gilg is a medicinal plant used extensively at the Kenya Coast for the treatment of various ailments. From solvent extracts of the root and stem barks of $\mathrm{O}$. holtzii, seven constituents were isolated by standard chromatographic techniques (CC, VLC, prep-TLC and Sephadex LH-20). Their structures were analyzed by MS, UV,IR, 1D and 2D NMR spectroscopy. All were found to be biflavonoids, including three novel compounds: dehydrate of lophirone $\mathrm{C}$, hotzinol, and tri-O-methyl lophirone A. Crude methanol extracts of $\mathrm{O}$. holtzii and the isolated biflavonoids were tested for antimicrobial activities against two Gram-positive bacteria, Staphylococcus aureus and Bacillus subtilis, two Gram-negative bacteria, Salmonella typhi and Pseudomonas aeruginosa, and the diploid fungus Candida albicans. The extracts and the isolated constituents showed varying levels of activities against the microbes. Afzelone $\mathrm{D}$, lophirone $\mathrm{A}$ and the novel tri-O-methyl lophirone A showed strong activities against $P$. aeruginosa and $S$. aureus, with the latter being more susceptible. Calodenin $B$ and the novel dehydrolophirone $C$ also showed strong activities against these bacteria, but were more active against $P$. aeruginosa. However, none of these matched those of the antibiotic Chloramphenicol or the antifungal Fluconazole. This represents the first study on phytochemical and antimicrobial profiles of $O$. holtzii.
\end{abstract}

Keywords: Ochnaholtzii Gil; Ochnaceae; Biflavonoids; Dehydrolophirone C; Holtzinol, Afzelone D O-methylether

\section{Introduction}

Ochna holtzii Gilg (Ochnaceae) is one of eight plant species of the genus Ochna that are found in Kenya [1]. Plants in this genus are known to be rich in biflavonoids, isoflavonoids and anthranoids [2-4]. Flavonoids exhibit a wide range of biological activities, and have been of particular interest as potential anticancer [5], anti-HIV-1 [6,7] and antibacterial agents and analgesics, as well as insecticides and insect antifeedants [8]. Moreover, flavonoids are effective antioxidants and antidotes for snake bites [9], and are considered to provide protection from cardiovascular diseases [10], certain forms of cancer and age related degeneration of cell components [11]. Ochnaholtzii is a plant found mainly at the coastal region of Kenya. The local communities use various parts of the plant (stem and root bark) to treat different health problems, including high fever, headaches and coughs, and to soothe persistent backaches, especially in old age [12]. It is also used extensively with other plant extracts in treating microbial infections [1]. The bio-activities of this plant and associated phytochemicals have not been systematically investigated. In the present study, we undertook chromatographic separation of solvent extracts of the stem and root bark, isolated and structurally characterized some of the constituents and compared their antimicrobial and antifungal activities with those of crude extracts. Herein we report our findings.

\section{Discussion}

Compound 1 was obtained as yellow crystals from the EtOAc stem bark extract of $O$. holtzii. The UV spectrum exhibited absorption peaks at $\lambda_{\max } 201,223$ and $274 \mathrm{~nm}$, characteristic of compounds with highly conjugated system [13]. EI-MS $(70 \mathrm{eV})$ gave $\mathrm{m} / \mathrm{z}$ at $526[\mathrm{M}+\mathrm{H}]^{+}$ corresponding to $\mathrm{C}_{30} \mathrm{H}_{20} \mathrm{O}_{8}$. This was further confirmed with NMR data including 1D NMR $\left({ }^{8} \mathrm{H},{ }^{13} \mathrm{C}\right.$ and DEPT) and 2D NMR (COSY, HSQC, HMBC and NOESY) spectra. The ${ }^{1} \mathrm{H}$ NMR spectrum displayed 15 signals of which thirteen (13) appeared in the aromatic region and 2 were olefinic with $J_{\mathrm{H}-\mathrm{H}}=15.4 \mathrm{~Hz}$ characteristic of a trans-configuration. The ${ }^{13} \mathrm{C}$ NMR spectrum had 24 distinct signals for 30 carbon atoms, 2 of which were carbonyl carbon atoms and over 12 associated with several aromatic rings. Chemical shifts assignments were made from the analysis of ${ }^{1} \mathrm{H}-{ }^{-1} \mathrm{H}$ COSY, $\mathrm{HMBC}$ and $\mathrm{HMQC}$ spectra. From the analysis of the ${ }^{1} \mathrm{H}^{-1} \mathrm{H}$ COSY spectrum, the aromatic protons were distributed into one para-disubstituted, three ortho, para-trisubstituted aromatic ring systems and a dehydrobenzofuran moiety. The structure of compound $\mathbf{1}$ was confirmed from the analysis of its HMBC spectrum. The ${ }^{1} \mathrm{H}$ and ${ }^{13} \mathrm{C}$ NMR spectra of the compound closely compared with the spectral data of lophirone C [14], a compound isolated previously from Ochnaafzelii. The main difference was the presence of two quaternary carbon signals at $\delta 156.2$ and 114.5 at positions $\alpha_{2}$ and $\beta_{2}$, respectively, in compound $\mathbf{1}$, indicating a complete furene ring, while in lophirone $\mathrm{C}$, the two carbon signals were aliphatic at $\delta 88.6$ and 57.6, respectively, as shown in (Table 1). Compound $\mathbf{1}$ was named dehydrolophirone $\mathrm{C}$.

Compound 2 was obtained as a yellow solid from stem bark. It gave $\mathrm{m} / \mathrm{z}$ at $527[\mathrm{M}+\mathrm{H}]^{+}$corresponding to $\mathrm{C}_{30} \mathrm{H}_{22} \mathrm{O}_{9}$ with EIMS $(70 \mathrm{eV})$, and MS fragmentation pattern, $1 \mathrm{D}$ NMR $\left({ }^{1} \mathrm{H},{ }^{13} \mathrm{C}\right.$ and DEPT) and $2 \mathrm{D}$ NMR (COSY, HSQC, HMBC and NOESY) spectra identical to those of lophirone $\mathrm{K}$ [3]. Compound $\mathbf{3}$ was obtained from the stem bark as yellow crystals. It gave $\mathrm{m} / \mathrm{z}$ at $449[\mathrm{M}+\mathrm{H}]^{+}$with EI-MS $(70 \mathrm{eV})$.The molecular formula was deduced as $\mathrm{C}_{24} \mathrm{H}_{16} \mathrm{O}_{9}$ and further confirmed by NMR data, including $1 \mathrm{D}$ NMR $\left({ }^{1} \mathrm{H},{ }^{13} \mathrm{C}\right.$ and DEPT) and $2 \mathrm{D}$ NMR (COSY, HSQC, HMBC and NOESY) spectra. The ${ }^{1} \mathrm{H}$ NMR spectrum displayed 10 signals and eight (8) of these appeared in the aromatic region.Eight of the ten signals (1D and $2 \mathrm{D}$ NMR) were very similar to those of $\alpha, \beta$-unsaturated olefin moiety and $\mathrm{B} 1$ and $\mathrm{B} 2$ aromatic rings of lophirone $\mathrm{C}[14]$ and dehydrolophirone $\mathrm{C}$. The main difference was absence in compound 3 of aromatic $\mathrm{C}-\mathrm{H}$ signals corresponding to the para-disubstituted ring $\mathrm{A}_{2}$ (Table 1). In addition, lack of one

*Corresponding author: Awadh MM, Department of Chemistry, Kenyatta University, P.O. Box 43844-00100, Nairobi, Kenya, Tel: 254720100520; E-mail: awadhmm99@yahoo.com

Received August 07, 2014; Accepted September 05, 2014; Published September 07, 2014

Citation: Awadh MM, Tarus PK, Onani MO, Machocho AK, Hassanali A (2014) Biflavonoids from an Ethno-Medicinal Plant Ochna holtzii Gilg. Nat Prod Chem Res 2: 149. doi:10.4172/2329-6836.1000149

Copyright: (c) 2014 Awadh MM. This is an open-access article distributed under the terms of the Creative Commons Attribution License, which permits unrestricted use, distribution, and reproduction in any medium, provided the original author and source are credited. 


\begin{tabular}{|c|c|c|c|c|c|c|}
\hline \multirow[t]{2}{*}{ Position } & \multicolumn{2}{|r|}{ Compound 1} & \multicolumn{2}{|r|}{ Compound 3} & \multicolumn{2}{|r|}{ Compound 7} \\
\hline & $\delta \mathrm{C}$ & $\delta \mathrm{H}(\mathrm{ppm}), \mathrm{m}^{*},(\mathrm{~J}(\mathrm{~Hz}))$ & $\delta \mathrm{C}$ & $\delta \mathrm{H}(\mathrm{ppm}), \mathrm{m}^{*},(\mathrm{~J}(\mathrm{~Hz}))$ & $\delta \mathrm{C}$ & $\delta \mathrm{H}(\mathrm{ppm}), \mathrm{m}^{*},(\mathrm{~J}(\mathrm{~Hz}))$ \\
\hline $\mathrm{B}_{1}-1$ & $114.7 \mathrm{~s}$ & & $114.7 \mathrm{~s}$ & & $117.0 \mathrm{~s}$ & \\
\hline$B_{1}-2$ & $167.6 \mathrm{~s}$ & & $167.7 \mathrm{~s}$ & & $159.2 \mathrm{~s}$ & \\
\hline $\mathrm{B}_{1}-3$ & $103.8 \mathrm{~d}$ & $6.20(1 \mathrm{H}, \mathrm{d}, \mathrm{J}=2.2 \mathrm{~Hz})$ & $103.9 \mathrm{~d}$ & $6.27(1 \mathrm{H}, \mathrm{d}, \mathrm{J}=2.2 \mathrm{~Hz})$ & $103.3 \mathrm{~d}$ & $6.69(1 \mathrm{H}, \mathrm{d}, \mathrm{J}=2.2 \mathrm{~Hz})$ \\
\hline $\mathrm{B}_{1}-4$ & $166.7 \mathrm{~s}$ & & $166.7 \mathrm{~s}$ & & $165.8 \mathrm{~s}$ & \\
\hline $\mathrm{B}_{1}-5$ & $109.3 d$ & $6.34(1 \mathrm{H}, \mathrm{dd}, \mathrm{J}=9.0,2.2 \mathrm{~Hz})$ & $108.8 \mathrm{~d}$ & $6.42(1 \mathrm{H}, \mathrm{dd}, \mathrm{J}=2.2,9.1 \mathrm{~Hz})$ & $116.1 \mathrm{~d}$ & $6.83(1 \mathrm{H}, \mathrm{dd}, \mathrm{J}=2.2,8.9$ \\
\hline $\mathrm{B}_{1}-6$ & $133.7 \mathrm{~d}$ & $7.91(1 \mathrm{H}, \mathrm{d}, \mathrm{J}=9.0 \mathrm{~Hz})$ & $133.2 \mathrm{~d}$ & $8.10(1 \mathrm{H}, \mathrm{d}, \mathrm{J}=9.1 \mathrm{~Hz})$ & $128.2 \mathrm{~d}$ & $7.85(1 \mathrm{H}, \mathrm{d}, \mathrm{J}=8.9 \mathrm{~Hz})$ \\
\hline $\mathrm{C}_{1}$ & $193.3 \mathrm{~s}$ & & 192. $8 \mathrm{~s}$ & & $177.1 \mathrm{~s}$ & \\
\hline$a_{1}$ & $121.4 \mathrm{~d}$ & $7.70(1 \mathrm{H}, \mathrm{d}, \mathrm{J}=15.4 \mathrm{~Hz})$ & $119.3 \mathrm{~d}$ & $7.72(1 \mathrm{H}, \mathrm{d}, \mathrm{J}=15.4 \mathrm{~Hz})$ & $122.4 \mathrm{~s}$ & \\
\hline$\beta_{1}$ & $145.2 \mathrm{~d}$ & $7.83(1 \mathrm{H}, \mathrm{d}, \mathrm{J}=15.4 \mathrm{~Hz})$ & $144.8 \mathrm{~d}$ & $7.85(1 \mathrm{H}, \mathrm{d}, \mathrm{J}=15.4 \mathrm{~Hz})$ & $157.4 \mathrm{~d}$ & $8.22(1 \mathrm{H}, \mathrm{s})$ \\
\hline$A_{1}-1$ & $130.8 \mathrm{~s}$ & & $129.3 \mathrm{~s}$ & & $135.7 \mathrm{~s}$ & \\
\hline$A_{1}-2$ & $122.1 \mathrm{~d}$ & $7.71(1 \mathrm{H}, \mathrm{d}, \mathrm{J}=2.0 \mathrm{~Hz})$ & $126.9 \mathrm{~s}$ & & $129.8 \mathrm{~d}$ & $7.16(2 \mathrm{H}, \mathrm{d}, \mathrm{J}=8.4 \mathrm{~Hz})$ \\
\hline$A_{1}-3$ & $132.5 \mathrm{~s}$ & & $132.1 \mathrm{~s}$ & & $116.1 \mathrm{~d}$ & $6.56(2 \mathrm{H}, \mathrm{d}, \mathrm{J}=8.4 \mathrm{~Hz})$ \\
\hline$A_{1}-4$ & $158.2 \mathrm{~s}$ & & $158.9 \mathrm{~s}$ & & $157.4 \mathrm{~s}$ & \\
\hline$A_{1}-5$ & $112.8 \mathrm{~d}$ & $7.58(1 \mathrm{H}, \mathrm{d}, \mathrm{J}=8.8 \mathrm{~Hz})$ & $111.0 \mathrm{~d}$ & $6.95(1 \mathrm{H}, \mathrm{d}, \mathrm{J}=8.8 \mathrm{~Hz})$ & $116.1 \mathrm{~d}$ & $6.56(2 \mathrm{H}, \mathrm{d}, \mathrm{J}=8.4 \mathrm{~Hz})$ \\
\hline$A_{1}-6$ & $126.8 \mathrm{~d}$ & $7.74(1 \mathrm{H}, \mathrm{d}, \mathrm{J}=8.8,2.0 \mathrm{~Hz})$ & $132.1 \mathrm{~d}$ & $7.50(1 \mathrm{H}, \mathrm{d}, \mathrm{J}=8.8 \mathrm{~Hz})$ & $129.8 \mathrm{~d}$ & $7.16(2 \mathrm{H}, \mathrm{d}, \mathrm{J}=8.4 \mathrm{~Hz})$ \\
\hline $\mathrm{C}_{2}$ & $196.1 \mathrm{~s}$ & & $196.5 \mathrm{~s}$ & & $204.8 \mathrm{~s}$ & \\
\hline$\alpha_{2}$ & $114.5 \mathrm{~s}$ & & $113.3 \mathrm{~s}$ & & $44.6 \mathrm{~d}$ & $6.02(1 \mathrm{H}, \mathrm{d}, \mathrm{J}=12.2 \mathrm{~Hz})$ \\
\hline$\beta_{2}$ & $156.2 \mathrm{~s}$ & & $153.3 \mathrm{~s}$ & & $54.3 \mathrm{~d}$ & $4.70(1 \mathrm{H}, \mathrm{d}, \mathrm{J}=12.2 \mathrm{~Hz})$ \\
\hline$A_{2}-1$ & $121.4 \mathrm{~s}$ & & & & $135.8 \mathrm{~s}$ & \\
\hline$A_{2}-2,6$ & $130.6 \mathrm{~d}$ & $7.48(2 \mathrm{H}, \mathrm{d}, \mathrm{J}=8.4 \mathrm{~Hz})$ & & & $130.5 d$ & $7.16(2 \mathrm{H}, \mathrm{d}, \mathrm{J}=8.4 \mathrm{~Hz})$ \\
\hline $\mathrm{A}_{2}-3,5$ & $116.7 \mathrm{~d}$ & $6.71(2 \mathrm{H}, \mathrm{d}, \mathrm{J}=8.4 \mathrm{~Hz})$ & & & $114.6 \mathrm{~d}$ & $6.56(2 \mathrm{H}, \mathrm{d}, \mathrm{J}=8.4 \mathrm{~Hz})$ \\
\hline $\mathrm{A}_{2}-4$ & $160.8 \mathrm{~s}$ & & & & $164.5 \mathrm{~s}$ & \\
\hline $\mathrm{B}_{2}-1$ & $114.6 \mathrm{~s}$ & & $115.3 \mathrm{~s}$ & & $115.0 \mathrm{~s}$ & \\
\hline $\mathrm{B}_{2}-2$ & $167.5 \mathrm{~s}$ & & $166.1 \mathrm{~s}$ & & $166.8 \mathrm{~s}$ & \\
\hline $\mathrm{B}_{2}-3$ & $103.8 d$ & $6.27(1 \mathrm{H}, \mathrm{d}, \mathrm{J}=2.2 \mathrm{~Hz})$ & $103.3 \mathrm{~d}$ & $6.38(1 \mathrm{H}, \mathrm{d}, \mathrm{J}=2.2 \mathrm{~Hz})$ & $101.7 \mathrm{~d}$ & $6.28(1 \mathrm{H}, \mathrm{d}, \mathrm{J}=2.3 \mathrm{~Hz})$ \\
\hline $\mathrm{B}_{2}-4$ & $167.3 \mathrm{~s}$ & & $166.1 \mathrm{~s}$ & & $168.0 \mathrm{~s}$ & \\
\hline $\mathrm{B}_{2}-5$ & $109.5 \mathrm{~d}$ & $6.05(1 \mathrm{H}, \mathrm{dd}, \mathrm{J}=8.8,2.2 \mathrm{~Hz})$ & $109.0 \mathrm{~d}$ & $6.49(1 \mathrm{H}, \mathrm{dd}, \mathrm{J}=2.2,8.0 \mathrm{~Hz})$ & $108.5 \mathrm{~d}$ & $6.34(1 \mathrm{H}, \mathrm{dd}, \mathrm{J}=2.3,9.0)$ \\
\hline $\mathrm{B}_{2}-6$ & $136.7 \mathrm{~d}$ & $7.23(1 \mathrm{H}, \mathrm{d}, \mathrm{J}=8.8 \mathrm{~Hz})$ & $136.5 \mathrm{~d}$ & $7.97(1 \mathrm{H}, \mathrm{d}, \mathrm{J}=8.0 \mathrm{~Hz})$ & $134.4 \mathrm{~d}$ & $8.14(1 \mathrm{H}, \mathrm{d}, \mathrm{J}=9.0 \mathrm{~Hz})$ \\
\hline $\mathrm{A}_{1}-4-\mathrm{OCH}_{3}$ & & & & & $49.5 q$ & $3.76(3 \mathrm{H}, \mathrm{s})$ \\
\hline $\mathrm{A}_{2}-4-\mathrm{OCH}_{3}$ & & & & & $56.1 \mathrm{q}$ & $3.76(3 \mathrm{H}, \mathrm{s})$ \\
\hline $\mathrm{B}_{2}-4-\underline{\mathrm{OCH}}_{3}$ & & & & & $55.5 q$ & $3.66(3 \mathrm{H}, \mathrm{s})$ \\
\hline
\end{tabular}

Table 1: ${ }^{1} \mathrm{H}$ and ${ }^{13} \mathrm{C}$ NMR data for compounds 1,3 and 7.

aromatic proton associated with ring $\mathrm{A}_{1}$ and presence of two doublets at $\delta 7.50$ and $6.95(\mathrm{~J}=8.8 \mathrm{~Hz})$ showed the presence of a hydroxyl group at position 2 of the ring. These spectral features led to assignment of structure 3 for the compound which was named holtzinol

Compound 4 was obtained as orange needles from the root bark that gave $m / z 524[\mathrm{M}+\mathrm{H}]^{+}$corresponding to $\mathrm{C}_{30} \mathrm{H}_{20} \mathrm{O}_{9}$ with EIMS (70eV), and MS fragmentation pattern, 1D NMR $\left({ }^{1} \mathrm{H},{ }^{13} \mathrm{C}\right.$ and DEPT) and 2D NMR (COSY, HSQC, HMBC and NOESY) spectra identical to those of calodenin B [3].

Compound 5 was obtained from the root bark that gave $\mathrm{m} / \mathrm{z}$ $511[\mathrm{M}+\mathrm{H}]^{+}$corresponding to $\mathrm{C}_{30} \mathrm{H}_{22} \mathrm{O}_{8}$ with EIMS $(70 \mathrm{eV})$, and MS fragmentation pattern, 1D NMR $\left({ }^{1} \mathrm{H},{ }^{13} \mathrm{C}\right.$ and DEPT) and 2D NMR (COSY, HSQC, HMBC and NOESY) spectra identical to those of lophirone A [15].

Compound 6 was obtained as a brown solid from stem bark that gave $\mathrm{m} / \mathrm{z} 539[\mathrm{M}+\mathrm{H}]^{+}$, corresponding to $\mathrm{C}_{32} \mathrm{H}_{26} \mathrm{O}_{8}$ with EIMS $(70 \mathrm{eV})$, MS fragmentation pattern, 1D NMR $\left({ }^{1} \mathrm{H},{ }^{13} \mathrm{C}\right.$ and DEPT) and $2 \mathrm{D}$ NMR (COSY, HSQC, HMBC and NOESY) spectra identical to those ofafzelone D [14].

Compound 7 was obtained as yellow crystals from the EtOAc root bark extract. It gave $\mathrm{m} / \mathrm{z}$ at $534[\mathrm{M}+\mathrm{H}]^{+}$corresponding to $\mathrm{C}_{33} \mathrm{H}_{28} \mathrm{O}_{8}$, which was confirmed by NMR data, including $1 \mathrm{D}$ NMR $\left({ }^{1} \mathrm{H},{ }^{13} \mathrm{C}\right.$ and DEPT) and 2D NMR (COSY, HSQC, HMBC and NOESY) spectra. The ${ }^{1} \mathrm{H}$ NMR spectrum of 7 displayed 19 signals. Two singlets at $\delta 3.76$ and 3.66, integrated for three and six methoxyl protons, respectively. The six protons singlet indicated that the two methoxyl groups are symmetrically positioned. The other 17 signals were very similar with respect to shifts and splitting pattern with those of lophirone A [15] and afzelone D [16] reported earlier. The existence of three methoxyl groups implied that compound 7 was tri-methoxy derivative of lophirone A, that is, lophirone A trimethyl ether (Figure 1 and Table 1).

\section{Biological activity}

The root methanolic crude extract exhibited higher antimicrobial properties against $S$. aureus, $P$. aeruginosa and B. subtilis compared to those of the stem bark extract (Table 2). The isolated compounds showed varying levels of activities against the two gram positive and two gram negative bacteria, as well as against the diploid fungus. Lophirone A, afzelone D and lophirone Atrimethyl ether also showed strong activities against these bacteria. Likewise, calodenin $\mathrm{B}$ and dehydrolophirone $\mathrm{C}$ showed also strong activities against the bacteria as well as against $C$. albicans. Further studies on related compounds that may be isolated from other Ochna and related plant species are expected to shed some light on the structural requirements for antimicrobial activities of this group of natural products. In addition, it would be interesting to extend the study to other bioactivities of these bioflavonoids. For example, calodenin B was previously found to exhibit cytotoxicity against breast cancer cells [17], and Lophirone A was reported to inhibit Epstein-Barr virus [18]. This biflavanoid has also been reported to exhibit potent cytotoxicity activity against 


\begin{tabular}{|c|c|c|c|c|c|c|c|c|c|c|}
\hline \multirow{3}{*}{ Isolate/extract } & \multicolumn{10}{|c|}{ Micro-organisms } \\
\hline & \multicolumn{2}{|c|}{ S. aureus } & \multicolumn{2}{|c|}{$P$. aeruginosa } & \multicolumn{2}{|c|}{ B. subtilis } & \multicolumn{2}{|c|}{ S. typhi } & \multicolumn{2}{|c|}{ C. albicans } \\
\hline & (Z-I) & MIC & $(Z-I)$ & MIC & $(Z-I)$ & MIC & $(Z-I)$ & MIC & $(Z-I)$ & MIC \\
\hline Stem $\mathrm{MeOH}$ crude & 20 & 500 & 19 & 1000 & 23 & 250 & 17 & 1500 & 13 & NT \\
\hline Root MeOHcrude & 26 & 250 & 22 & 500 & 26 & 200 & 16 & 1500 & 14 & NT \\
\hline Dehydrolophirone C (1) & 21 & 250 & 24 & 500 & 23 & 250 & 15 & 1500 & 18 & NT \\
\hline Holtzinol (3) & 16 & 1000 & 14 & 1500 & 16 & 2000 & 12 & 1500 & 10 & NT \\
\hline Calodenin B & 20 & 250 & 25 & 250 & 23 & 250 & 15 & 1500 & 22 & NT \\
\hline Lophirone A & 24 & 200 & 21 & 500 & 25 & 250 & 15 & 1500 & 17 & NT \\
\hline Afzelone D & 23 & 200 & 20 & 500 & 25 & 250 & 15 & 1500 & 17 & NT \\
\hline Tri-O-methylLophirone A (7) & 23 & 200 & 20 & 500 & 24 & 250 & 14 & 1500 & 16 & NT \\
\hline Chloramphenicol & 32 & 36 & 31 & 59 & 32 & 48 & 20 & 200 & - & - \\
\hline Fluconazole & - & - & - & - & - & - & - & - & 26 & 72 \\
\hline
\end{tabular}

Z-I = Zone of inhibition in $\mathrm{mm}$; MIC = Minimum Inhibitory Concentration in $\mu \mathrm{g} / \mathrm{ml}$

Table 2: Anti-microbial activities of methanolic extracts of root and stem barks of $O$. holtzii and isolated compounds.<smiles>O=C(Nc1cc(C=CC(=O)c2ccc(O)cc2O)ccc1OC(=O)c1ccc(O)cc1O)c1ccc(O)cc1</smiles>

(1)

$\mathrm{HO}$<smiles>[R19]C(O)Oc1ccc(/C=C/C(=O)c2ccc(O)cc2O)c(O)c1O</smiles>

(3)

(6) $\mathrm{R} 1=\mathrm{R} 2=\mathrm{Me} \mathrm{R} 3=\mathrm{H}$

(7) $\mathrm{R} 1=\mathrm{R} 2=\mathrm{R} 3=\mathrm{Me}$

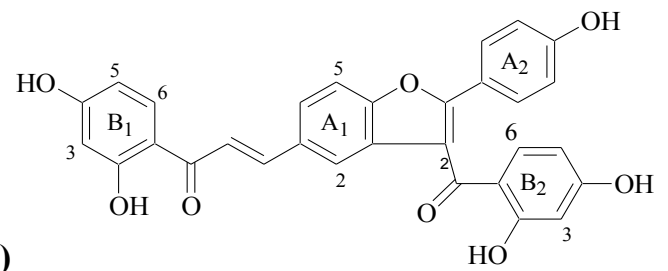

(2)<smiles>O=C(Oc1c(C(=O)Oc2cc(O)ccc2C(=O)C=Cc2ccc(O)cc2)c(O)cc(O)c1C(=O)c1ccc(O)cc1O)c1ccc(O)cc1</smiles><smiles>[R20]Oc1ccc([C@H](c2ccc([R20])cc2)[C@@H](C(=O)c2coc3cc(O)ccc3c2=O)c2ccc(O[R20])cc2)cc1</smiles>

(4)

Figure 1: Biflavonoids isolated from the Ochna holtzii Gilg.

melanoma (UACC62), renal (TK10) and breast (MCF10) cancer cell lines [19]. Recently, Ajiboye found that lophirone C has relatively high anticancer, antimutagenic, and antioxidant activities [20]. Thus, although our results with $\mathrm{O}$. holtzii and its constituents provide some scientific rationale for the use of this ethno-medicinal plant by the communities of the coastal region of Kenya, it also suggests the need for extending the study to other Ochna species and other bioactivities.

\section{Experimental}

\section{Spectral measurements}

${ }^{1} \mathrm{H}(1 \mathrm{D}, 2 \mathrm{D} \mathrm{COSY})$ and ${ }^{13} \mathrm{C}$ spectra were recorded using Varian Gemini $400 \mathrm{MHz}$ (NMR) instrument using $\mathrm{CD}_{3} \mathrm{OD}$ as solvent. Peaks on ${ }^{1} \mathrm{H}$-NMR were recorded as singlet $(s)$, doublet $(d)$, doublet of doublet $(d d)$, triplet $(t)$, quartet $(q)$ and (or) broad $(b)$ using internal standard TMS as reference. The ${ }^{13} \mathrm{C}$-NMR multiplicity was determined by DEPT experiments. Chemical shifts were recorded in $\delta$ (ppm) and coupling constants, J, in Hertz (Hz). Standard sequences were used for COSY, HMQC, HMBC and NOESY experiments. IR: KBr pellets technique.

\section{Chromatographic techniques}

These include CC: silica gel 60 (0.063-0.200 mm, Merck); VLC and TLC: silica gel $60 \mathrm{~F}_{254}$ (Merck) precoated aluminum plates; Sephadex LH-20 used as filter gel; and $p$-anisaldehyde spray with UV-Vis was used for visualization.

\section{Disc diffusion assay}

The crude extracts and the isolated compounds were tested for 
antimicrobial activities using agar diffusion technique against two Gram-positive, Bacillus subtilis and Staphylococcus aureus, two Gramnegative, Salmonella typhi (Type K [1]) and Pseudomonas aeruginosa, and a yeast Candida albicans. The plate diffusion method was used. Chloramphenicol was used as positive control. $14 \mathrm{~g}$ of nutrient agar was dissolved in 0.51 of distilled water. Round filter paper MN 615 of $9 \mathrm{~cm}$ diameter was punched and the paper pieces sterilized. Nutrient agar $(15 \mathrm{ml})$ was poured into Petri dishes in a lamina flow apparatus under sterile conditions. Then $0.1 \mathrm{ml}$ of bacterial solution was added to it. Filter paper pieces containing $100 \mu \mathrm{g}$ of the test extract were put on Petri dish and then finally incubated at $37^{\circ} \mathrm{C}$ for bacteria or $30^{\circ} \mathrm{C}$ for fungi. The results observed were recorded by measuring the diameter of the zone of inhibition from original $6 \mathrm{~mm}$.

\section{Determination of MIC}

The MIC was determined using two-fold serial dilution method in a peptone water solution for bacterial and PDA broth for yeast and fungal of the active extracts. Each tube was then inoculated with 0.1 $\mathrm{ml}$ of standardized bacterial suspension $\left(1 \times 10^{8} \mathrm{CFU} / \mathrm{ml}\right)$ and fungal suspension $\left(1 \times 10^{8}\right.$ spores $\left./ \mathrm{ml}\right)$. The cultures were then incubated at $37^{\circ} \mathrm{C}$ for 24 hours for bacteria, 48 hours for yeast and at $30^{\circ} \mathrm{C}$ for 72 hours for fungi. The first tube showing no growth was the MIC.

\section{Plant materials}

The stem and root barks of O. holtzii were collected from ArabukoSokoke Forest, Malindi, Kilifi County of Coast province in Kenya in April 2010. The plant was authenticated by Mr. Lucas Karimi, Department of Complementary Medicine, Kenyatta University. A voucher specimen (No. MM/002/10) was deposited at the herbarium of the Kenya National Museums, Nairobi.

\section{Method of extraction and isolation}

Air-dried stem and root barks of $O$. holtzii were separately ground to give fine powders (5.58 and $7.23 \mathrm{~kg}$, respectively) and each was extracted separately using solvents of increasing polarity sequentially (starting with hexane, then DCM, followed by EtOAc and finally $\mathrm{MeOH}$ ) for 48 hrs each with occasional swirling to ensure thorough extraction. The extracts were decanted and filtered through Whattman filter paper and the marcerate steeped in solvent again for $48 \mathrm{hrs}$. The extraction process was repeated 3 times when a clear extract was obtained. The filtrates were combined and concentrated using rotary evaporator under reduced pressure and a temperature of $45^{\circ} \mathrm{C}$. A small portion of each crude extract was used for bioassays. Evaporation of the solvent from the stem bark ethyl acetate extract yielded $40 \mathrm{~g}$ of a dark brown residue. This extract was subjected to fractionation by Vacuum Liquid Chromatography (VLC) on silica gel with a Hexane:DCM DCM:MeOH gradient (100:0-0:100) to yield $172 \times 50 \mathrm{ml}$ fractions. Fractions were combined after TLC comparison, which were then fractionated by column chromatography on silica gel using a gradient mixture of $\mathrm{DCM} / \mathrm{MeOH}$, starting from pure DCM, followed by $50: 50$ blends to pure $\mathrm{MeOH}$. Fractions of $50 \mathrm{ml}$ each were collected and these were subjected to further purification using Sephadex (L-20) column 1:1 (DCM:MeOH)and prep-TLC with the combined fractions using 1:1 (DCM:MeOH). Through this procedure, compound $\mathbf{1}$ was obtained. Using same procedure, other compounds isolated from the stem were lophirone K (2) [3] and afzelone D (6) [16]. A similar procedure was used with the $9 \mathrm{~g}$ root bark ethyl acetate extract and fractions were combined on the basis of TLC comparison and subjected to further purification. Thus, calodenin B (4)[3], lophirone A (5)[13], and compounds 3 and 7 were isolated from the root extract.

\section{Dehydrolophirone C (1)}

Yellow crystals, MP $198-200^{\circ} \mathrm{C}$

IR (KBr): 2926 (br), 3356, 1620, 1512, $2962 \mathrm{~cm}^{-1}$.

UV $\lambda_{\text {max }} 201,223$ and $274 \mathrm{~nm}$

1H and 13C NMR: Table 1.

EI-MS m/z (\%) 207 (100), $509\left(1,[\mathrm{M}+\mathrm{H}]^{+}\right), 433$ (2), 417 (3), 389 (4), 355 (5), 281 (24), 259 (5), 241 (8), 222 (5), 191 (10), 147 (21), 133 (7), 129 (100), $112(19), 96(8), 83(12), 73$ (9), , 55 (2).

\section{Holtzinol (3)}

Yellow crystals, MP $178-180^{\circ} \mathrm{C}$

UV $\lambda_{\text {max }}: 201,224$ and $274 \mathrm{~nm}$

IR (KBr): 2926 (br), 3410, 2962, 1627, $1512 \mathrm{~cm}^{-1}$.

$1 \mathrm{H}$ and 13C NMR: Table 1.

EI-MS m/z (\%) $207(100), 449\left(1,[\mathrm{M}+\mathrm{H}]^{+}\right), 429(2), 390$ (3), 355 (5), 281 (24), 222 (5), 259 (5), 241 (8), 191 (15), 147 (21), 133 (7), 129 (100), 112 (19), 96 (8), 83 (12), 73 (9), 71 (22), 57 (30), 55 (2).

\section{Lophirone A trimethyl ether (7)}

Yellow crystals.MP $192-194^{\circ} \mathrm{C}$.

$\mathrm{UV} \lambda_{\text {max }}: 218,282 \mathrm{~nm}$

IR (KBr): 2926 (br), 3256, 2963, 1605, $1512 \mathrm{~cm}^{-1}$.

$1 \mathrm{H}$ and 13C NMR: Table 1.

EI-MS m/z (\%) $207(100), 534\left(2,[\mathrm{M}+\mathrm{H}]^{+}\right), 428(1), 355$ (4), 341 (2), 306 (19), 281 (26), 214 (100), 197 (12), 183 (41), 181 (18), 163 (3), 152 (11), 149 (6), 135 (9), 133 (10), 121 (23), 108 (30), 94 (65), 77 (10), 73 (9), 65 (17), 55 (7).

\section{Acknowledgment}

We are grateful to Kenyatta University and its technical staff for providing space and some apparatus used in this work. We thank AICAD (the African Institute for Capacity Development) for partial funding of the project. We also appreciate Mr. Lucas Karimi, Department of Pharmacy and Complementary Medicine for authenticating the plant.

\section{References}

1. Beentje H (1994) Kenya trees, shrubs and lianas. National Museums of Kenya Nairobi 368-372.

2. Khalivulla S, Reddy N, Reddy B, Reddy R, Gunasekar D et al. (2008) A new biflavanone from Ochnalanceolata. Natural Products Communications3: 1487 1490.

3. Messanga BB, Tin RG, Sondengam BL, Martin MT, Bodo B (1994) Biflavonoids from O. calodendron .Phytochemistry 35: 791-794.

4. Sibanda S, Nyamira C, Nicoletti M, Galeffi C (1990) Ochnabianthrone; a trans 9,9'-bianthrone from O. pulchra. Phytochemistry29: 394-396.

5. Wang B, Zhang X (2012) Inhibitory effects of Broccolini leaf flavonoids on human cancer cells. Scanning 34:1-5

6. Mehla R, Bivalkar MS, Chauhan A (2011) A Flavonoid, Luteolin, Cripples HIV-1 by Abrogation of Tat Function. Plos one 6: e27915.

7. Reutrakul V, Ningnuek N, Pohmakotr M, Yoosook C, Napaswad C et al. (2007) Anti HIV-1 flavonoid glycosides from Ochnaintegerrima. Planta Medica73: 683-688

8. Cushnie TP, Lamb AJ (2011) Recent advances in understanding the antibacteria properties of flavonoids. Int J Antimicrob Agents 38: 99-107.

9. Imam S, Gupta VC, Husain SJ (2003) Some important folk-herbal medicines used as antidotes for snake bites from tribal pockets of Atmakur forest division of Andhra Pradesh. National Symposium on emerging trends in Indian Medicinal Plants. 
10. Guzey M (2013) Consumption of the dietary flavonoids and cancer.

11. Priya B, Sharma AK (2013) Anticancer potential of flavonoids: recent trends and future perspectives. Biotechnology 3: 439-459.

12. Kokwaro JO (1996) Medicinal plants of East Africa. Nairobi. E. AfricanLiterature Bureau384.

13. Kemp W (2009) Organic spectroscopy 4: 132-183.

14. Tih AE, Ghogomu TR, Sondengam BL, Martin MT,Bodo B (1990) Biflavonoids from Lophiraalata. Journal of Natural Products 53: 964-965

15. Ghogomu TR, Sondengam BL, Martin MT,Bodo B (1987) Lophirone A, a biflavonoid with unusual skeleton from Lophiralanceoalata. Tetrahedron letters 28: 2967-2968.

16. Pegnyemb DE, Ghogomu TR, Sondengam BL, Blond A,Bodo B (2003) Isolation and structure elucidation of a new isobiflavonoid from Ochnaafzelii. Pharmaceutical Biology41: 92-95.
17. Tang S, Bremner P, Kortenkamp A, Schlage C, Gray Al et al.(2003) Biflavonoids with cytotoxic and antibacterial activity from Ochnamacrocalyx. Planta Medica 69: $247-253$

18. Murakami A, Tanaka S, Ohigashi H, Irie R, Takeda N et al. (1991) Inhibitory effects of new types of biflavonoid-related polyphenols; lophirone $A$ and lophiraic acid, on some tumor promoters-induced biological activities in vivo and in vitro. Cancer Letters 58: 101-106.

19. Ndoile MM(2012) Structure, synthesis and biological activities of biflavonoids isolated from Ochnaserrulata (Hochst.) WalpPhD Thesis.

20. Ajiboye TO, Yakubu MT, Oladiji AT (2014) Cytotoxic, antimutagenic, and antioxidant activities of methanolic extract and chalcone dimers (lophirones B and C) derived from Lophiraalata (Van Tiegh. Ex Keay) stem bark. J Evid Based Complementary Altern Med 19: 20-30. 